\title{
Bilateral post-arterial puncture pseudoaneurysm in a patient with amyloidosis
}

\author{
Pseudoaneurisma bilateral pós-punção arterial em paciente com amiloidose \\ Paula Sabrina Araújo Milhomem¹, Marcelo Luiz Brandão', Werther Souza Sales', \\ Juliano Ricardo Santana dos Santos' ${ }^{1}$ Rodrigo Alves Riemma' ${ }^{1}$ Viviane Queli Macedo de Alcântara'
}

\begin{abstract}
Amyloidosis consists of deposition of insoluble fibrillar proteins in tissues and, causing dysfunction. In association with other factors, the condition can contribute to emergence of complications, such as pseudoaneurysms at arterial puncture sites. Pseudoaneurysms are becoming an ever-more common complication, which underscores the importance of identifying risk factors, so that their incidence can be minimized.
\end{abstract}

Keywords: amyloidosis; pseudoaneurysm; catheterization.

\section{Resumo}

A amiloidose consiste em um depósito de proteínas fibrilares insolúveis em tecidos e órgãos, causando disfunção nos mesmos, e pode contribuir, associada a outros fatores, para formação de complicações, como pseudoaneurisma em locais de punção arterial. O pseudoaneurisma consiste de uma complicação cada vez mais frequente e, por isso, a importância de se identificarem seus fatores de risco, para que, então, sua incidência possa ser minimizada.

Palavras-chave: amiloidose; pseudoaneurisma; cateterismo. 


\section{INTRODUCTION}

The increasing number of endovascular procedures has led to ever more frequent cases of iatrogenic formation of false aneurysms after arterial catheterization. ${ }^{1}$ Hypertension and drugs that affect coagulation are among the most common causes. ${ }^{1}$ Unusual comorbidities can also contribute to complications at puncture sites, such as, for example, systemic amyloidosis. The incidence of pseudoaneurysms after catheterization via the femoral in diagnostic procedures varies from 0.1 to $2.0 \%$, reaching $5 \%$ in therapeutic procedures. ${ }^{1,2}$

The amyloidoses are a heterogeneous group of diseases that involve deposition of insoluble fibrillar proteins in tissues and organs. There are abnormalities of protein folding that cause deposition of insoluble amyloid fibrils, primarily in the extracellular spaces of organs and tissues. The result is dysfunction of the surrounding tissue. ${ }^{3}$

There are a range of treatment options for iatrogenic pseudoaneurysms and the choice of which to employ depends on size of injury, the artery involved, and other factors. Expectant conservative management can be considered in cases of small lesions, measuring less than $2 \mathrm{~cm} \cdot{ }^{4-6}$ Larger injuries than this are unlikely to exhibit spontaneous closure of the puncture orifice, and so some type of intervention will be necessary. Another aspect that should be taken into account is the factor that caused the pseudoaneurysm. If the patient exhibits other comorbidities that make it less likely that the orifice will heal, such as amyloidosis for example, these conditions should also contribute to the choice of treatment option.

This article describes the clinical case of a patient with amyloidosis who suffered a pseudoaneurysm at an arterial puncture site.

\section{CASE REPORT}

The patient was a 68 -year-old with difficult to control hypertension, on dialysis for chronic kidney disease and with amyloidosis diagnosed during a renal biopsy. In October of 2011 the patient had undergone cardiac catheterization and a few days later angioplasty of the coronaries, with femoral artery puncture. The patient reported bilateral formation of small nodules at the puncture sites. The patient was on dual antiplatelet aggregation therapy. In January of 2012, the patient developed a pulsating mass in the left groin (Figures 1 and 2) and minor non-pulsating nodulation contralaterally. Investigation with color
Doppler showed a pseudoaneurysm in the left femoral artery.

The decision was taken to adopt a conservative approach to the non-pulsating contralateral nodulation, which measured $1 \mathrm{~cm}$. A surgical approach was chosen for the pseudoaneurysm (Figure 3).

Repairs were made proximal and distal to the injury, dissecting the left external iliac and left superficial femoral arteries. The injury itself was then treated with dissection of the pseudocapsule and excision of the thrombus (Figure 4). A punctiform lesion with active bleeding was found at the puncture

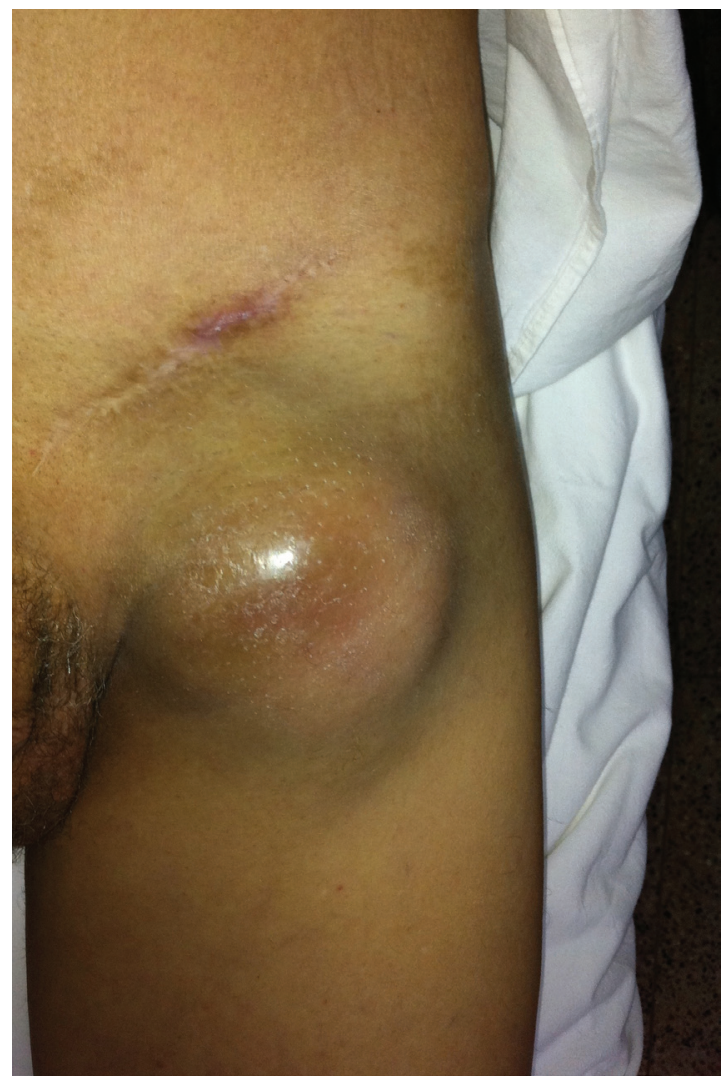

Figure 1. Pseudoaneurysm in the left femoral artery.

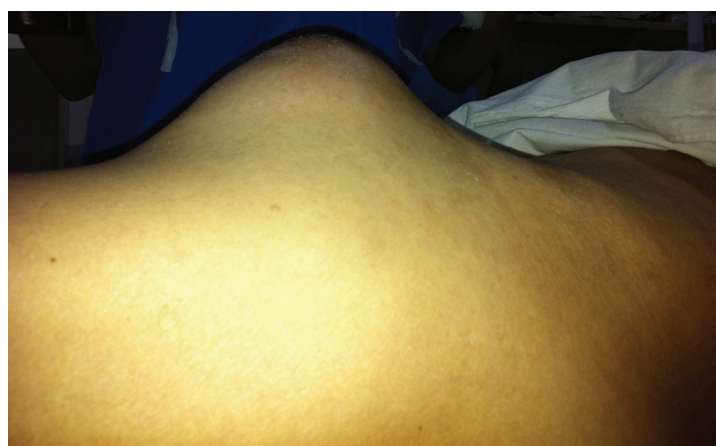

Figure 2. Pseudoaneurysm in the left femoral artery: lateral view. 


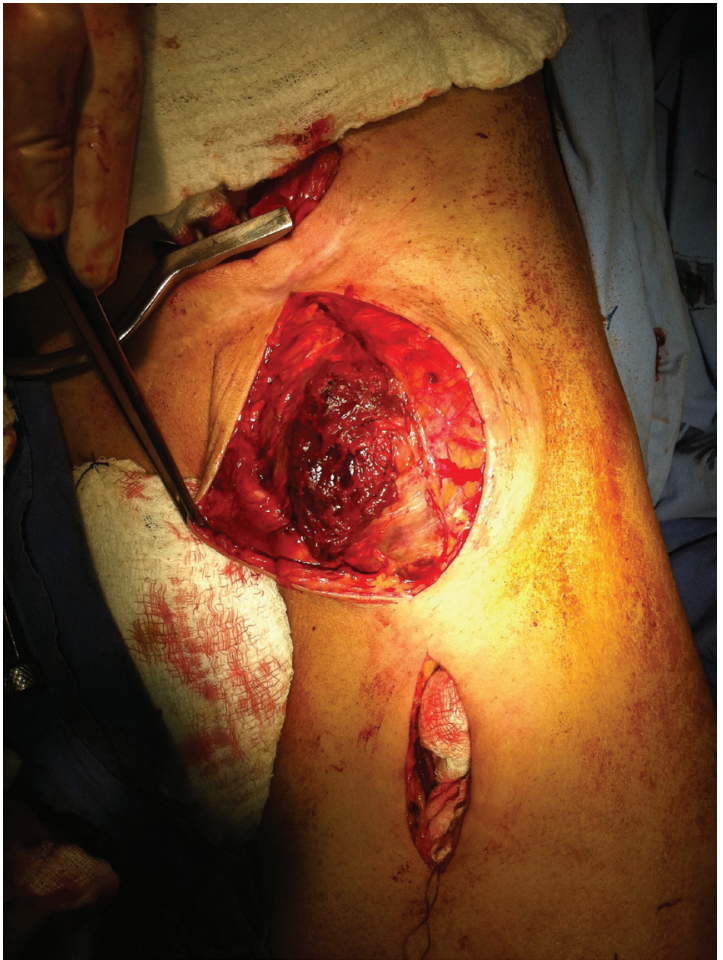

Figure 3. Surgical accesses.

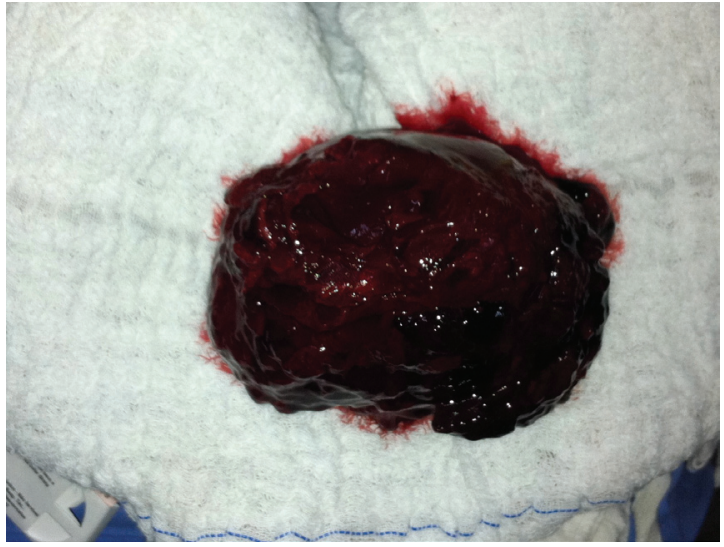

Figure 4. Thrombus removed from the pseudoaneurysm.

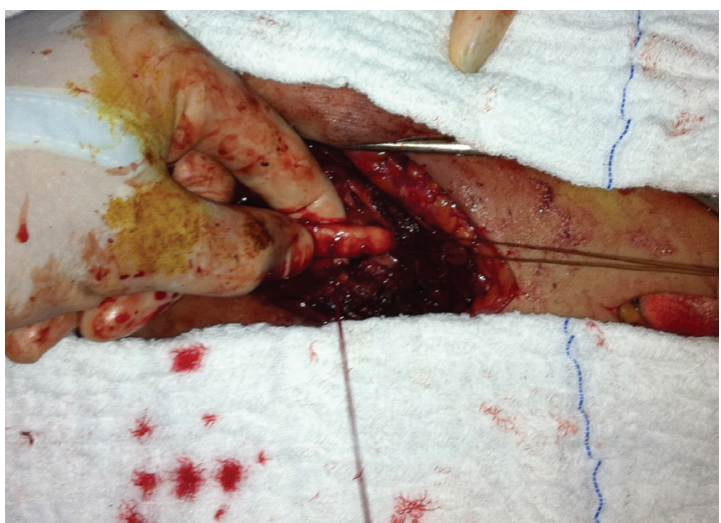

Figure 5. Punctiform injury with active bleeding in the left common femoral artery: at puncture site.

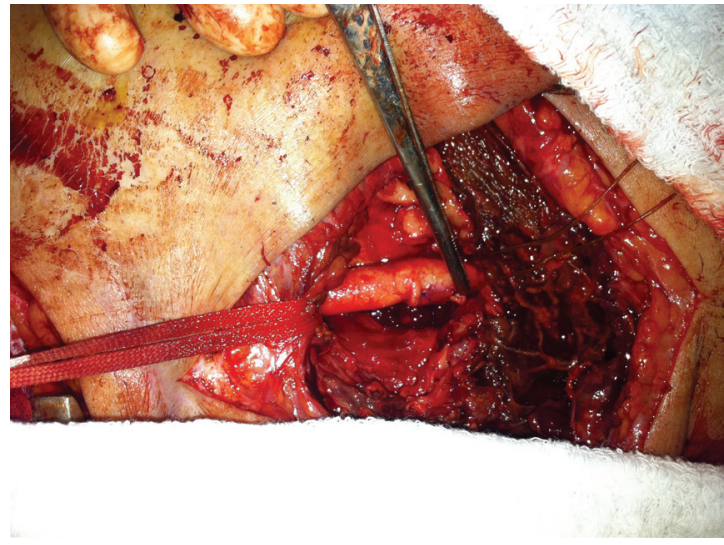

Figure 6. Arteriorrhaphy.

site (Figure 5) and duly repaired by arteriorrhaphy (Figure 6).

A segment of the arterial branch was sent for pathology studies, which identified destruction of elastic fibers, without amyloid deposition.

The patient recovered well after the procedure, was discharged from hospital and is currently in outpatients follow-up, with no intercurrent conditions, and attending regular consultations with a nephrologist.

\section{DISCUSSION}

False aneurysms occur more frequently among older people and have direct associations with anticoagulation and hypertension. ${ }^{1,2}$ Comorbidities, such as amyloidosis, appear to contribute to this type of complication; but the relationship has not yet been proven scientifically.

Treatment of post-puncture arterial pseudoaneurysms can range from conservative management, for lesions smaller than $2 \mathrm{~cm}$ - through compression with the Doppler machine transducer and injection of thrombin - to conventional surgical or endovascular treatment. ${ }^{2,5,7}$ For many years the only treatment option was immediate open repair to prevent expansion and complications, such as thromboembolism. Nowadays, variants of the same technique and less-invasive alternatives are options in certain cases. ${ }^{5,6}$

The case described here exhibited a large volume pseudoaneurysm, with onset 3 months previously, causing discomfort to the patient. The decision to conduct treatment with conventional surgery was founded on the need not only to correct the arterial injury, but also to remove the large clot. Even though less invasive techniques now exist, in certain 
situations open surgical treatment appears to remain the best option.

Pseudoaneurysms are becoming an ever-more common complication, which underscores the importance of identifying risk factors - such as systemic diseases - so that their incidence can be minimized.

\section{REFERENCES}

1. Weinmann EE, Bass A. Post-catheterization false aneurysms. Isr Med Assoc J. 2001;3(1):39-40. PMid:11344801.

2. Pereira MM, Marassi JP, Silva OB, Pires LJI, Santos LN, Petean Filho $\mathrm{H}$, et al. Pseudoaneurisma pós-cateterismo: tratamento. J Vasc Bras. 2011;10(2):177-80. http://dx.doi.org/10.1590/ S1677-54492011000200015.

3. Seldin D, Sanchorawala V.Adapting to AL amyloidosis. Haematologica. 2006;91(12):1591-5.

4. Kresowik TF, Khoury MD, Miller BV, Winniford MD, Shamma AR, Sharp WJ, et al. A prospective study of the incidence and natural history of femoral vascular complications after percutaneous transluminal coronary angioplasty. J Vasc Surg. 1991;13(2):328-35. http://dx.doi.org/10.1016/0741-5214(91)90226-K. PMid:1990173

5. Norwood MG, Lloyd GM, Moore S, Patel N, Panditi S, Sayers RD. The changing face of femoral artery false aneurysms. Eur J Vasc Endovasc Surg. 2004;27(4):385-8. http://dx.doi.org/10.1016/j.ejvs.2004.01.001. PMid:15015188

6. Gioppato S, Munhoz A, Marins M, Conforti TB, Castello HJ, Cantarelli MJC, et al. Tratamento Percutâneo de Pseudoaneurismas por Injeção de Trombina Guiada por Ultrassom. Rev Bras Cardiol Invasiva. 2010;18(2):165-70.
7. Matic P, Babic S, Tanaskovic S, Jocic D, Radak D. Treatment of infected pseudoaneurysm of femoral artery after vascular closure device deployment: a practical solution. Case Rep Vasc Med. 2012; 2012:292945. http://dx.doi.org/10.1155/2012/292945.

Correspondence Paula Sabrina Araújo Milhomem Endereço completo: Rua C258, 519/1702, Setor Nova Suíça CEP 74280-210 - Goiânia (GO), Brazi Tel.: +55 (62) 3998-2115/ +55 (62) 32593663/ +55 (62) 99512151 E-mail: psmilhomem@hotmail.com

Author information PSAM is a resident physician of Vascular Surgery at Hospital das Clínicas da Universidade Federal de Goiás (UFG) MLB is a full professor and head of the Service of Vascular Surgery at Hospital das Clínicas da Universidade Federal de Goiás (UFG). WSS is a resident physician of Vascular Surgery at Hospital das Clínicas da Universidade Federal de Goiás (UFG). JRSS is a resident physician of Vascular Surgery at Hospital das Clínicas da Universidade Federal de Goiás (UFG) RAR is a resident physician of Vascular Surgery at Hospital das Clínicas da Universidade Federal de Goiás (UFG) VQMA is a resident physician of Endovascular Surgery at Hospital das Clínicas da Universidade Federal de Goiás (UFG)

Author contributions Conception and design: PSAM, MLB Analysis and interpretation: MLB, JRSS, WSS, RAR, VQMA Data collection: PSAM, WSS, VQMA Writing the article: PSAM, JRSS, WSS Critical revision of the article: MLB, RAR Final approval of the article*: PSAM, MLB, VQMA, WSS, JRSS, RAR Statistical analysis: N/A Overall responsibility: PSAM, MLB

${ }^{*}$ All authors have read and approved of the final version of the article submitted to J Vasc Bras. 